\section{Genetic Polymorphism in MMP9 May Be Associated With Anterior Open Bite in Children}

Erika Calvano Küchler ${ }^{1}$, Driely Barreiros ${ }^{1}$, Raphaela Oliveira da Silva ${ }^{2}$, Júlia Guimarães Barcellos de Abreu², Ellen Cardoso Teixeira ${ }^{3}$, Raquel Assed Bezerra da Silva ${ }^{1}$, Lea Assed Bezerra da Silva ${ }^{1}$; Paulo Nelson Filho ${ }^{1}$, Fábio Lourenço Romano ${ }^{1}$, José Mauro Granjeiro ${ }^{4}$, Livia Azeredo Alves Antunes ${ }^{3}$, Leonardo Santos Antunes ${ }^{2,3}$

\author{
'Department of Pediatric Dentistry, \\ School of Ribeirão Preto, USP \\ - Universidade de São Paulo, \\ Ribeirão Preto, SP, Brazil \\ ${ }^{2}$ Clinical Research Unit, \\ UFF - Universidade Federal \\ Fluminense, Niterói, RJ, Brazil \\ ${ }^{3}$ Department of Specific Formation, \\ Dental School of Nova Friburgo, UFF \\ - Universidade Federal Fluminense, \\ Nova Friburgo, RJ, Brazil \\ ${ }^{4}$ Bioengineering Program, \\ INMETRO - Instituto Nacional \\ de Metrologia, Qualidade e \\ Tecnologia, Xerém, RJ, Brazil
}

Correspondence: Erika Calvano Küchler, Avenida do Café s/n, Monte Alegre, 14090-904. Ribeirão Preto, SP, Brasil. Tel: +55-16-3315-3995. e-mail: erikacalvano@gmail.com

Key Words: polymorphism, genetics, anterior open bite, dental malocclusion.

\section{Introduction}

Anterior Open Bite (AOB) is a dentoalveolar or skeletal malocclusion in the vertical plane (1), with the lack of contact of opposing teeth when posterior teeth are in occlusion (2). AOB malocclusion is multifactorial condition involving a combination of many factors. Sucking habits and facial characteristics such as bone, teeth and soft tissue alterations are involved in AOB etiology (3).

Non-nutritive sucking habits such as finger and pacifier sucking $(4,5)$ and nutritive sucking habit like breast and bottle-feeding $(6,7)$ are reported to be involved in $A O B$ etiology. It is also possible that $A O B$ is influenced by genetic factors $(3,8)$, in which genes that play a role in facial bone growth and development, teeth and soft tissue, may be associated with AOB.

Matrix metalloproteinases (MMPs) are a group of enzymes responsible for the degradation of most extracellular matrix proteins $(9,10)$. The MMPs are inhibited by specific endogenous tissue inhibitors of metalloproteinases (TIMPs). Both, MMPs and TIMPs, are involved in tissue modelling and remodeling (11-13) and play an important role during organogenesis, growth and normal tissue turnover (14).

Although there is no published paper on the association between $A O B$ and genetic factors, it is plausible to hypothesize that genetic factors act in combination with sucking habits establishing the AOB in children. Therefore, the aim of this study was to evaluate the association between polymorphism in MMP2, MMP3, MMP9, TIMP1 and TIMP2 genes with AOB.

\section{Material and Methods Subject Screening}

This study was submitted and approved by the Human Ethics Committee of Antônio Pedro Hospital of Universidade Federal Fluminense (Process \#811.473). All parents or caregivers were informed about the study and signed an informed consent.

The sample was collected in 30 public daycare centers from Nova Friburgo, a city in the State of Rio de Janeiro, in the southeast region of Brazil, from May 2012 to October 2013. The parents/caregivers answered a questionnaire about the children's characteristics and habits.

Children with primary dentition whose parents reported at least one sucking habit were selected regardless the type of sucking (finger sucking, pacifier sucking and bottle feeding use).

The selected children were clinically examined by a 
pediatric dentist and $\mathrm{AOB}$ were considered when occurred with a minimum vertical gap of $0.5 \mathrm{~mm}$ between the maxillary and mandibular incisors in centric occlusion. Children with history of previous orthodontic treatment or speech therapy, children with other malocclusion than $A O B$ and children with syndromes or oral cleft were not included.

\section{DNA Extraction and Real-Time PCR Assay}

Genomic DNA for molecular analysis was extracted from saliva using a previously reported method (15). Genotyping of the selected polymorphisms in MMP2, MMP3, MMP9, TIMP1 and TIMP2 was carried out by real-time PCR using the Stratagene Mx3005P (Agilent Techologies, SAN Diego, CA, USA) with TaqMan method that expresses each sample as a homozygotic or heterozygotic according to the detected fluorescence.

\section{Statistical Analysis}

Student's t test was used to evaluate age difference and chi-square test was used to analyze gender and ethnicity distribution between the group with $A O B$ and the group without $A O B$, using the Epi Info 7.0 software $\vec{s}$ at a $5 \%$ level of significance.

PLINK ${ }^{\circledR}$ software was used to evaluate genotype and allele distribution between the group with $A O B$ and the group without $A O B$ in a free model and in a recessive model. For MMP2, MMP3, MMP9 and TIMP2, that are located in autosomal chromosome, chi-square test was used. For TIMP1, located in a sex chromosome, a multivariate analysis was performed and gender was used as a covariant in the model. The level of significance was set at $5 \%$.
Logistic regression analysis was implemented using duration of the sucking habit, breastfeeding, ethnicity, gender and polymorphisms MMP2, MMP3, MMP9, TIMP1 and TIMP2 as covariates in order to evaluate possible interactions.

The standard chi-square test was used to test for deviation from Hardy-Weinberg equilibrium.

\section{Results}

Among the 472 analyzed children, 219 had AOB and 253 had normal occlusion. The age ranged between 2 and 6 years old. AOB was more frequent in girls than in boys $(p=0.015 ; O R \quad 1.5,95 \% \mathrm{Cl} 1.0-2.2)$. Age and ethnicity were not different between groups ( $p>0.05)$. In $88 \%(n=417)$ of the cases, the mothers reported breastfeeding their children for at least 12 months.

Table 1 presents the results of the genotypes and alleles distribution between the groups.

The polymorphism rs17576 in MMP9 $(p=0.009)$ was significantly associated with $A O B$. In a recessive model ( $G G$ versus $A G+A A$ ), $G G$ genotype was a protective factor for $A O B(p=0.014 ; O R \quad 4.6,95 \% C l$ 1.3-16.2). The other analyzed polymorphisms were not statistically different between the groups ( $p>0.05$ ).

The logistic regression analysis is presented in the Table 2. There was no association between the polymorphisms in MMP2, MMP3, MMP9, TIMP1 and TIMP2 and AOB ( $p>0.05$ ). Breastfeeding was not associated with $A O B$ in the logistic regression analysis $(p=0.09)$.

\section{Discussion}

$A O B$ is commonly classified as skeletal or dental malocclusion. The dental open bite is generally found in

Table 1. Genotype and allele distribution between the groups

\begin{tabular}{|c|c|c|c|c|c|c|c|c|c|c|c|c|c|}
\hline \multirow{4}{*}{$\begin{array}{l}\text { Gene } \\
\text { MMP2 }\end{array}$} & \multicolumn{7}{|c|}{ Genotype distribution (\%) } & \multicolumn{6}{|c|}{ Allele distribution (\%) } \\
\hline & \multicolumn{3}{|c|}{$\begin{array}{l}\text { Group without AOB } \\
\qquad(\mathrm{n}=219)\end{array}$} & \multicolumn{3}{|c|}{$\begin{array}{l}\text { Group with AOB } \\
\qquad(n=253)\end{array}$} & \multirow{3}{*}{$\begin{array}{c}\mathrm{p} \\
\text { value }\end{array}$} & \multicolumn{2}{|c|}{$\begin{array}{l}\text { Group without AOB } \\
\qquad(\mathrm{n}=219)\end{array}$} & \multicolumn{2}{|c|}{$\begin{array}{l}\text { Group with } \\
\text { AOB }(n=253)\end{array}$} & \multirow{3}{*}{$\begin{array}{c}\mathrm{p} \\
\text { value }\end{array}$} & \multirow{3}{*}{$\begin{array}{c}\text { OR } \\
\text { (IC 95\%) } \\
0.95 \\
(0.71-1.28)\end{array}$} \\
\hline & $\mathrm{CC}$ & CT & $\mathrm{TT}$ & $\mathrm{CC}$ & $\mathrm{CT}$ & TT & & $\mathrm{T}$ & $\mathrm{C}$ & $\mathrm{T}$ & $\mathrm{C}$ & & \\
\hline & $29(14.3)$ & $89(43.8)$ & $85(41.9)$ & 21(11.7) & $84(46.9)$ & $74(41.3)$ & & $147(36.2)$ & $259(63.8)$ & $126(35.2)$ & $232(64.8)$ & & \\
\hline \multirow{2}{*}{ MMP3 } & GG & $\mathrm{AG}$ & AA & GG & AG & AA & \multirow{2}{*}{0.881} & G & A & G & A & \multirow{2}{*}{0.800} & 1.04 \\
\hline & $25(11.6)$ & $68(31.5)$ & $123(56.9)$ & $23(13.1)$ & $53(30.1)$ & $100(56.8)$ & & $118(27.3)$ & $314(72.7)$ & $99(39.1)$ & $253(60.9)$ & & $(0.76-1.42)$ \\
\hline \multirow{2}{*}{ MMP9 } & GG & $\mathrm{AG}$ & AA & GG & $\mathrm{AG}$ & AA & \multirow{2}{*}{0.009} & G & A & G & A & \multirow{2}{*}{0.709} & 0.93 \\
\hline & $16(10.7)$ & $57(38.2)$ & $76(51.0)$ & $3(2.5)$ & $61(51.7)$ & $54(45.8)$ & & $89(29.9)$ & $209(70.1)$ & $67(28.4)$ & $169(71.6)$ & & $(0.63-1.35)$ \\
\hline \multirow{2}{*}{ TIMP 1} & $\mathrm{CC}$ & $\mathrm{CT}$ & TT & $\mathrm{CC}$ & CT & TT & \multirow{2}{*}{0.359} & $\mathrm{C}$ & $\mathrm{T}$ & C & $\mathrm{T}$ & \multirow{2}{*}{0.237} & 1.22 \\
\hline & $26(14.8)$ & $51(29.0)$ & $99(56.2)$ & $18(11.8)$ & $66(43.4)$ & $68(44.7)$ & & $103(29.3)$ & $249(70.7)$ & $102(33.5)$ & $202(66.4)$ & & $(0.87-1.69)$ \\
\hline \multirow{2}{*}{ TIMP2 } & GG & GT & $\mathrm{TT}$ & GG & GT & $\mathrm{TT}$ & \multirow{2}{*}{0.196} & $\mathrm{G}$ & $\mathrm{T}$ & G & $\mathrm{T}$ & \multirow{2}{*}{0.072} & 0.67 \\
\hline & $9(4.7)$ & $48(25.0)$ & 135(70.3) & $3(1.8)$ & $34(21.0)$ & $125(77.1)$ & & $66(17.2)$ & $318(82.8)$ & $40(12.3)$ & $284(87.7)$ & & $(0.44-1.03)$ \\
\hline
\end{tabular}


the anterior region and is associated with sucking habits. On the other hand, the skeletal open bite is often related to excessive vertical growth of the dento-alveolar complex, especially in the posterior molar region (3) According to Lin et al. (2013) (3) the classification of AOB as either skeletal or dental is difficult, and it is probably a result of both factors in combination with sucking habits. Therefore, the present study selected a sample of children that presented sucking habits, in which $\mathrm{AOB}$ phenotype was characterized according to the clinical characteristics.

The effects of sucking habits on the development of the occlusion were under investigation for decades and several studies demonstrated their association with different types of malocclusion (4,16-20). The main question arising from these studies is whether genetic factors are a risk or a protective factor for AOB. For this reason, a genetical analysis was performed to evaluate if the MMP family contributes to the etiology of the AOB.

MMPs are a group of enzymes responsible for the degradation of most extracellular matrix proteins during growth (14). MMPs and TIMPs are expressed by osteoblasts (21-25) and play a role in bone development, modeling and remodeling. The present results demonstrated that MMP9 was associated with AOB. It was observed that GG genotype in MMP9 acted as a protective factor for AOB. MMP9 protein plays an important role in extracellular matrix remodeling by cleaving denatured collagen and type IV collagen in the basement membrane (24). It is interesting to note that the studied polymorphism rs 17576 in MMP9 is a non-synonymous substitution characterized by the amino acid substitution of glutamine to arginine (NCBI). Although the impact of this polymorphism on

Table 2. Regression analysis in the both cohorts

\begin{tabular}{lcccc}
\hline Gene & Reference & Genotype & p-value & OR (95\%CI) \\
\hline \multirow{2}{*}{ MMP2 } & CC & CT & 0.97 & $1.01(0.41-2.49)$ \\
& & TT & 0.83 & $1.09(0.45-2.66)$ \\
MMP3 & CC & CT & 0.71 & $0.84(0.32-2.15)$ \\
& & TT & 0.33 & $0.65(0.27-1.57)$ \\
MMP9 & AA & AG & 0.96 & $1.01(0.48-2.14)$ \\
& & GG & 0.14 & $0.18(0.01-1.79)$ \\
TIMP1 & CC & CT & 0.38 & $1.61(0.55-4.71)$ \\
& & TT & 0.33 & $0.61(0.22-1.65)$ \\
TIMP2 & GG & GT & 0.11 & $0.55(0.26-1.15)$ \\
& & TT & 0.43 & $0.47(0.07-3.07)$ \\
\hline
\end{tabular}

Note: OR (95\% C.I.)=Odds ratios; 95\% confidence intervals. Covariates included duration of the sucking habit, breastfeeding, ethnicity, gender and polymorphisms. protein function is unknown up to now, a previous study suggested that this polymorphism could lead to partial loss of function in extra-cellular matrix remodeling (25). The obtained results also suggested that this polymorphism presents a functional alteration that plays a role in the establishment of AOB.

Some evidences reinforce the hypothesis that genetic factors play an important role in the $\mathrm{AOB}$ etiology. Although some children presented sucking habits, they did not end up developing AOB. It may be hypothesized that some genes act as a protective factor against $A O B$ development.

This study has some obvious limitations. It is important to emphasize that it was decided to adopt a level of significance of 5\% to avoid type I error and to make it possible to identify small genetic effects of the genes on AOB etiology. Therefore, it is possible that the association between MMP9 rs17576 and AOB is a false-positive association since post-hoc analysis was not performed. Additionally, the logistic regression analysis was not able to confirm the results of the univariate analysis.

Another limitation of this study is the sample selection. Children were selected from daycare centers. These children did not present radiograph exams that allowed evaluating their morphological facial pattern. Different cephalometric measures are used to identify open bite tendency (26). Another fact to be highlighted is that an otorhinolaryngologic exam was not performed in order to evaluate nasal breathing and mouth breathing. This topic has been explored by some researchers in the past few decades. It is well known that the characteristic features of the increase in lower facial height and open bite are consistent with those attributed to nasal obstruction (2729). A study performed in teenagers using respirometric techniques to compare the breathing behavior of normal and long-faced patients demonstrated that the long-faced subjects had significantly smaller components of nasal respiration (29).

Although the present study did not observe an association between breast feeding and $A O B$, a previous study demonstrated that extending breastfeeding for 12 months was associated with a 3.7 times lower chance of having anterior open bite (30). It is possible that this result did not present a statistical significance due to the fact that $88 \%$ of the sample had extended breastfeeding.

To the best of the authors' knowledge, this is the first study to evaluate genetic factors involved in the etiology of the AOB. Further studies should be performed in order to confirm whether MMP9 is a protective factor for AOB, including other possible involved factors.

The polymorphism MMP9 rs17576 (glutamine for arginine substitution) was a protective factor for AOB. 
The obtained results support the hypothesis that $A O B$ is a multifactorial condition in which the combination of factors plays an important role.

\section{Resumo}

A mordida aberta anterior apresenta uma etiologia multifatorial causada pela interação entre hábitos de sucção e fatores genéticos. 0 objetivo deste estudo foi avaliar a associação entre mordida aberta anterior e polimorfismo nos genes que codificam as metaloproteinases da matriz (MMPs) e seus inibidores teciduais (TIMPs). Foram avaliadas 472 crianças que apresentvam pelo menos um hábito de sucção. As crianças foram clinicamente examinadas para avaliar a presença de mordida aberta anterior. DNA genômico foi extraido da saliva. A genotipagem dos polimorfismos selecionados em MMP2, MMP3, MMP9, TIMP1 e TIMP2 foi realizada por PCR em tempo real, usando o método de TaqMan. As frequências alélicas e genotípicas foram comparadas entre os grupos com e sem mordida aberta anterior usando o software PLINK ${ }^{\circledR}$. Duzentas e dezenove crianças apresentavam mordida aberta anterior enquanto 253 não a apresentavam. 0 polimorfismo rs17576 em MMP9 estava significativamente associado com mordida aberta anterior $(p=0,009)$. No modelo recessivo ( $G G$ versus $A G+A A$ ) o genótipo $G G$ foi um fator protetor para mordida aberta anterior $(p=0,014$; OR 4,6 ; $95 \% \mathrm{Cl} 1,3-$ 16,2). Concluindo, o polimorfismo rs 17576 (substituição de glutamina por arginina) em MMP9 está associado com mordida aberta anterior. 0s resultados obtidos suportam a hipótese de que fatores genéticos estão envolvidos com a etiologia da mordida aberta anterior.

\section{Acknowledgements}

¿ We are indebted to the participants of the study. Support for this work was provided by CNPq, FAPERJ and FAPESP (Grant 2015/06866-5). The authors declare no potential conflicts of interest with respect to the authorship and/or publication of this article.

\section{References}

1. Nielsen IL. Vertical malocclusions: etiology, development, diagnosis and some aspects of treatment. Angle Orthod 1991;61: 247-260.

2. Moyers RE. Handbook of orthodontics, 4th ed. Year Book Medical Publishers, Inc., USA 1988.

3. Lin LH, Huang GW, Chen CS. Etiology and treatment modalities of anterior open bite maloclussion. J Exp Clin Med 2013;5:1-4.

4. Heimer MV, Katz CR, Rosenblatt A. Non-nutritive sucking habits, dental malocclusions, and facial morphology in Brazilian children: a longitudinal study. Eur J Orthod 2008;30:580-585.

5. Piancino MG, Isola G, Merlo A, Dalessandri D, Debernardi C, Bracco P. Chewing pattern and muscular activation in open bite patients. J Electromyogr Kinesiol 2012;22:273-279.

6. Bueno SB, Bittar TO, Vazquez Fde L, Meneghim MC, Pereira AC. Association of breastfeeding, pacifier use, breathing pattern and malocclusions in preschoolers. Dental Press J Orthod 2013;18: 30.e1-6.

7. Garde JB, Suryavanshi RK, Jawale BA, Deshmukh V, Dadhe DP, Suryavanshi MK. An epidemiological study to know the prevalence of deleterious oral habits among 6 to 12 year old children. J Int Oral Health 2014;6:39-43.

8. Ngan P, Fields HW. Open bite: a review of etiology and management. Pediatr Dent 1997;19:91-98.

9. Nagase H, Woessner JF Jr. Matrix metalloproteinases. J Biol Chem 1999;274:21491-21494.

10. Page-McCaw A, Ewald AJ, Werb Z. Matrix metalloproteinases and the regulation of tissue remodeling. Nat Rev Mol Cell Biol 2007;8:221-233.

11. Birkedal-Hansen $H$, Moore WG, Bodden MK, Windsor $\sqcup$, BirkedalHansen B, DeCarlo A et al.. Matrix metalloproteinases: a review. Crit
Rev Oral Biol Med 1993:4:197-250.

12. Reynolds JJ. Collagenases and tissue inhibitors of metalloproteinases: a functional balance in tissue degradation. Oral Dis 1996;2:70-76.

13. Rohani MG, Parks WC. Matrix remodeling by MMPs during wound repair. Matrix Biol 2015; 44-46:113-121.

14. Sorsa T, Tjäderhane $L$, Salo T. Matrix metalloproteinases (MMPs) in oral diseases. Oral Dis 2004;10:311-318

15. Küchler EC, Tannure PN, Falagan-Lotsch P, Lopes TS, Granjeiro JM, Amorim LM. Buccal cells DNA extraction to obtain high quality human genomic DNA suitable for polymorphism genotyping by PCR-RFLP and Real-Time PCR. J Appl Oral Sci 2012;20:467-471.

16. Antonioli A, Marinelli A, Baroni G, Franchi L, Defraia E. Class II malocclusion with maxillary protrusion from the deciduous through the mixed dentition: a longitudinal study. Angle Orthod 2005;75:980986.

17. Vázquez-Nava $F$, Quezada-Castillo JA, Oviedo-Trevino $S$, SaldivarGonzález AH, Sánchez-Nuncio HR, Beltrán-Guzman FJ, et al. Association between allergic rhinitis, bottle feeding, non-nutritive sucking habits, and malocclusion in the primary dentition. Arch Dis Child 2006;91:836-840.

18. Góis EGO, Ribeiro-Júnior HC, Vale MPP, Paiva SM, Serra-Negra $J M$, Ramos-Jorge $M L$, et al.. Influence of nonnutritive sucking habits, breathing pattern and adenoid size on the development of malocclusion. Angle Orthod 2008;78:647-654.

19. Sexton S, Natale R. Risks and benefits of pacifiers. Am Fam Physician 2009;79:681-685.

20. Hermont AP, Martins CC, Zina LG, Auad SM, Paiva SM, Pordeus IA Breastfeeding, bottle feeding practices and malocclusion in the primary dentition: a systematic review of cohort studies. Int J Environ Res Public Health 2015;12:3133-3151.

21. Hatori K, Sasano $Y$, Takahashi I, Kamakura $S$, Kagayama M, Sasaki K. Osteoblasts and osteocytes express MMP2 and -8 and TIMP1, -2, and -3 along with extracellular matrix molecules during appositional bone formation. Anat Rec A Discov Mol Cell Evol Biol 2004;277:262-271.

22. Rocha CA, Cestari TM, Vidotti HA, Assis GF, Garlet GP, Taga R. Sintered anorganic bone graft increases autocrine expression of VEGF, MMP-2 and MMP-9 during repair of critical-size bone defects. J Mol Histol 2014;45:447-461.

23. Ozeki N, Hase N, Yamaguchi H, Hiyama $T$, Kawai $R$, Kondo $A$, et al.. Polyphosphate induces matrix metalloproteinase-3-mediated proliferation of odontoblast-like cells derived from induced pluripotent stem cells. Exp Cell Res 2015;333:303-315.

24. Awadalla MS, Burdon KP, Kuot A, Hewitt AW, Craig JE. Matrix metalloproteinase-9 genetic variation and primary angle closure glaucoma in a Caucasian population. Mol Vis 2011;17:1420-1424.

25. Wang IJ, Chiang TH, Shih YF, Lin LL, Shieh JW, Wang TH, et al.. The association of single nucleotide polymorphisms in the MMP-9 genes with susceptibility to acute primary angle closure glaucoma in Taiwanese patients. Mol Vis 2006;12:1223-1232.

26. Dung DJ, Smith RJ. Cephalometric and clinical diagnoses of open bite tendency. Am J Orthod Dentofacial Orthop. 1988;94:484-490.

27. Schendel SA, Jacobson R, Khalessi S. Airway growth and development: a computerized 3-dimensional analysis. J Oral Maxillofac Surg 2012;70:2174-2183.

28. Vig KW. Nasal obstruction and facial growth: the strength of evidence for clinical assumptions. Am J Orthod Dentofacial Orthop 1998;113:603-611.

29. Fields HW, Warren DW, Black K, Phillips CL. Relationship between vertical dentofacial morphology and respiration in adolescents. Am J Orthod Dentofacial Orthop 1991;99:147-154.

30. Romero CC, Scavone-Junior H, Garib DG, Cotrim-Ferreira FA, Ferreira RI. Breastfeeding and non-nutritive sucking patterns related to the prevalence of anterior open bite in primary dentition. J Appl Oral Sci 2011;19:161-168. 